\title{
Role of the Deletion Polymorphism of the Angiotensin Converting Enzyme Gene in the Progression and Therapeutic Responsiveness of IgA Nephropathy
}

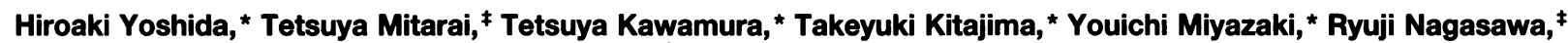 \\ Yoshindo Kawaguchi, ${ }^{*}$ Hitoshi Kubo, ${ }^{*}$ lekuni Ichikawa, ${ }^{\S}$ and Osamu Sakai* \\ *Department of Internal Medicine, Jikei University School of Medicine, Tokyo 105, Japan; ${ }^{\ddagger}$ Department of Internal Medicine, \\ Saitama Medical School, Kawagoe, Saitama 350, Japan; and ${ }^{\S}$ Department of Pediatrics, Vanderbilt University School of Medicine, \\ Nashville, Tennessee 37232
}

\begin{abstract}
Studies conducted over the last decade demonstrated variable therapeutic efficacy of angiotensin converting enzyme (ACE) inhibitor on the progression of glomerular diseases, including IgA nephropathy. In this study, among patients with biopsy-proven IgA nephropathy, 53 patients in whom creatinine clearance had been monitored over 5 yr were recruited for study. These patients were classified into two groups according to whether or not renal function had declined as determined by the slope of creatinine clearance against time: group 1 had stable renal function; group 2 had declining renal function (average: $-6.7 \pm 1.3 \mathrm{ml} / \mathrm{min} /$ yr). 21 of 53 patients were treated with $A C E$ inhibitor and followed for 48 wk. Gene polymorphism consisting of insertion (I) or deletion (D) of a 287-bp DNA fragment (presumed to be a silencer element) of the ACE gene was determined by PCR. 46 age-matched individuals without history of proteinuria were analyzed as controls. The DD genotype was significantly more frequent in group $2(43 \%)$ than in controls $(7 \%)$ or group 1 patients with stable renal function (16\%). 48 wk after ACE inhibitor administration, proteinuria significantly decreased in patients with DD genotype but not in those with ID or II genotypes. The results indicate that deletion polymorphism in the ACE gene, particularly the homozygote DD, is a risk factor for progression to chronic renal failure in IgA nephropathy. Moreover, this deletion polymorphism predicts the therapeutic efficacy of ACE inhibition on proteinuria and, potentially, on progressive deterioration of renal function. (J. Clin. Invest. 1995. 96:2162-2169.) Key words: chronic renal failure $\cdot$ reninangiotensin system $\bullet$ genetics $\cdot \mathrm{ACE}$ inhibitor $\bullet$ proteinuria
\end{abstract}

\section{Introduction}

Immunoglobulin A $(\operatorname{IgA})$ nephropathy is the most common form of glomerulonephritis in the world (1). Initially, the prog-

Address correspondence to Hiroaki Yoshida, M.D., Second Department of Internal Medicine, Jikei University School of Medicine, 3-25-8 NishiShinbashi Minato-ku, Tokyo 105, Japan. Phone: 3-3433-1111x3232; FAX: 3-3433-4297.

Received for publication 2 February 1995 and accepted in revised form 7 July 1995.

J. Clin. Invest.

(C) The American Society for Clinical Investigation, Inc. $0021-9738 / 95 / 11 / 2162 / 08 \$ 2.00$

Volume 96, November 1995, 2162-2169 nosis of IgA nephropathy was presumed to be benign; however, it is now recognized that $>50 \%$ of patients develop insidious chronic renal failure (2-6). The decline in renal function occurs slowly, steadily, and for the most part, silently, as does glomerulosclerosis. Such progressive deterioration of renal function and structure is not limited to IgA nephropathy but, rather, is common to many forms of chronic glomerular disease, and several key pathophysiologic mechanisms have been implicated in the progression (7).

Pharmacologic blockade of angiotensin I converting enzyme $(\mathrm{ACE})^{1}$ has been shown to significantly attenuate this progressive process in several experimental models $(8,9)$, suggesting the potential pathogenic role of the renin-angiotensin system. Most recently, a multicenter study conducted on patients with diabetic nephropathy in the United States (10) has confirmed the notion suggested earlier by several investigators (11-13) that ACE inhibitor ameliorates the progressive decline of renal function in diabetic patients. Although results are variable (14, $15)$, some studies $(16,17)$ also indicate that ACE inhibitor reduces proteinuria and attenuates progressive decline in renal function in IgA nephropathy as well. Of note, the important pathophysiologic role of the renin-angiotensin system has also been implicated in progressive disorders of the heart, notably cardiac hypertrophy and ischemic heart disease. While multiple studies have suggested an existence of correlation between genetic background in the renin-angiotensin system with evidence of heart disease (18-26), one conducted in Germany by Schunkert et al. is of particular interest (26). They studied the human ACE gene, which consists of 26 exons and spans $\sim 21$ $\mathrm{kb}$ on chromosome 17 (27). A deletion polymorphism of a 287-bp fragment of intron 16 of the ACE gene was detected. This polymorphism was found to be associated with the frequency of left ventricular hypertrophy (26). While this deletion polymorphism is associated with elevated serum and cellular ACE levels $(28,29)$, its association with blood pressure levels or ischemic heart disease varies between populations of different genetic and environmental backgrounds (21, 30-34). Of interest, the study of Schunkert et al. (26) demonstrated that the association between the deletion polymorphism and left ventricular hypertrophy is significantly stronger when analysis is limited to normotensive individuals, suggesting that the polymorphism may influence local pathogenic events which involve renin-angiotensin. In this study, we have examined the possible role of the ACE deletion polymorphism on another target of renin-angiotensin - the kidney - and its association with the progressive loss of renal function in IgA nephropathy. Since

1. Abbreviations used in this paper: ACE, angiotensin converting enzyme; $\mathrm{C}_{\mathrm{Cr}}$, creatinine clearance; $\mathrm{D}$, deletion; I, insertion. 
Table I. Data from Controls and Patients with IgA Nephropathy at the Time of Renal Biopsy

\begin{tabular}{lcccc}
\hline & $\begin{array}{c}\text { Group 1 } \\
(n=25)\end{array}$ & $\begin{array}{c}\text { Group 2 } \\
(n=28)\end{array}$ & $\begin{array}{c}\text { Control } \\
(n=46)\end{array}$ & \\
\hline $\begin{array}{l}\text { Age (yr)* } \\
\text { Male:Female }\end{array}$ & $38.2 \pm 2.1$ & $39.9 \pm 2.1$ & $35.8 \pm 1.8$ & NS \\
$\begin{array}{c}\text { Time lag from the } \\
\text { onset (yr) }\end{array}$ & $17: 8$ & $17: 11$ & $24: 22$ & NS \\
$\begin{array}{c}\text { Blood pressure } \\
\quad(m m H g)\end{array}$ & $8.2 \pm 1.3$ & $6.8 \pm 1.1$ & & NS \\
$\begin{array}{c}\text { Systolic } \\
\text { Diastolic }\end{array}$ & $123.4 \pm 2.4$ & $133.9 \pm 3.9$ & & \\
$\begin{array}{c}\text { Urinary protein } \\
\quad \text { excretion } \\
\text { (grams/24 h) }\end{array}$ & $18.7 \pm 2.8$ & $85.3 \pm 2.3$ & & NS \\
$\mathrm{C}_{\mathrm{cr}}$ (m1/min) & $89.5 \pm 4.3$ & $74.8 \pm 4.7$ & & \\
\hline
\end{tabular}

Values are given as means \pm SE. Patients with declining renal function (group 2) were compared with patients with stable renal function (group 1). Probabilities were determined by unpaired $t$ test. ${ }^{*}$ Data were compared between control, group 1, and group 2 by one-way ANOVA with factorial analysis. ${ }^{\ddagger}$ Data were compared between control, group 1 , and group 2 by multiple contingency table analysis.

specific pharmacologic agents are now available to lower ACE activity, identification of such a potential risk factor could enable us to devise a possible therapeutic intervention.

\section{Methods}

Patient population. Among 398 biopsy-proven Japanese patients with IgA nephropathy who visited the outpatient unit of Jikei Hospital, Tokyo, from April 1994 to July 1994, all of the patients who fulfilled the following criteria on July 1994 were recruited: $(a)$ having been followed over $10 \mathrm{yr}$ since the onset of initial symptoms; $(b)$ having been regularly measured for 24 -h creatinine clearance $\left(\mathrm{C}_{\mathrm{Cr}_{\mathrm{r}}}\right)$ for at least $5 \mathrm{yr}$; and $(c)$ having provided informed consent before entry into the study. They consisted of 53 patients ( 20 female and 33 male, ranging in age from 21 to $65 \mathrm{yr}$ ). In our practice, we routinely perform renal biopsy in patients with proteinuria $>0.5$ grams $/ 24 \mathrm{~h}$. Patients who had single kidney, anatomical abnormality such as horse shoe kidney or a bleeding tendency were excluded.

According to the rate of decline in renal function, estimated by the slope, over time, of $\mathrm{C}_{\mathrm{Cr}_{\mathrm{r}}}$ which was determined every $4 \mathrm{mo}$, these patients were classified into two groups: 25 patients showed stable renal function (group 1); and $\mathrm{C}_{\mathrm{Cr}}$ decreased in 28 patients (group 2). The mean slope of the $\mathrm{C}_{\mathrm{Cr}}$ in group 2 patients was $-6.73 \pm 1.25 \mathrm{ml} / \mathrm{min}$ (range: -1.62 $\mathrm{ml} / \mathrm{min} / \mathrm{yr}$ to $-21.80 \mathrm{ml} / \mathrm{min} / \mathrm{yr}$ ). These patients included 14 patients who required chronic dialysis within $10 \mathrm{yr}$ after the onset of initial symptoms. The clinical and laboratory features of controls and these two groups of patients at the time of renal biopsy are summarized in Table I. Means of age and sex distributions were not distinguishable between controls and patient groups. In group 1, the mean period of observation after the onset of initial symptoms ( $13.7 \pm 0.8 \mathrm{yr})$ was similar to that in group $2(12.0 \pm 1.3 \mathrm{yr})$. The mean values of urinary protein excretion rate in group 2 were not significantly different from those in group 1. The systolic blood pressure of the patients in group 2 was higher, on average, than that in group $1(P<0.05)$. The mean value of $\mathrm{C}_{\mathrm{Cr}_{\mathrm{r}}}$ at the time of renal biopsy in group 2 patients was lower than that of group $1(P<0.05)$. 46 healthy subjects without history of proteinuria ( 22 and 24 of whom were female and male, respectively, ranging in age from 19 to $57 \mathrm{yr}$ ) were analyzed as controls.
Table II. Baseline Data from Patients Subjected to the Study of ACE Inhibitor Administration

\begin{tabular}{|c|c|c|c|}
\hline & $\begin{array}{c}\mathrm{DD} \\
(n=9)\end{array}$ & $\begin{array}{c}\text { ID } \\
(n=6)\end{array}$ & $\begin{array}{c}\text { II } \\
(n=6)\end{array}$ \\
\hline Age (yr) & $53.2 \pm 4.1$ & $42.3 \pm 5.1$ & $50.7 \pm 4.6$ \\
\hline Male:Female* & $7: 2$ & $3: 3$ & $5: 1$ \\
\hline Group 1:group 2* & $2: 7$ & $3: 3$ & $4: 2$ \\
\hline Urinary protein (grams/24 h) & $1.41 \pm 0.41$ & $1.39 \pm 0.18$ & $1.43 \pm 0.35$ \\
\hline Serum creatinine $(\mathrm{mg} / \mathrm{dl})$ & $1.31 \pm 0.12$ & $1.03 \pm 0.06$ & $1.05 \pm 0.09$ \\
\hline $\mathrm{C}_{\mathrm{cr}}(\mathrm{ml} / \mathrm{min})$ & $71.7 \pm 8.9$ & $81.7 \pm 3.4$ & $80.1 \pm 7.7$ \\
\hline \multicolumn{4}{|l|}{ Blood pressure } \\
\hline Systolic pressure (mmHg) & $134 \pm 6$ & $120 \pm 5$ & $137 \pm 5$ \\
\hline $\begin{array}{l}\text { Diastolic pressure } \\
\quad(\mathrm{mmHg})\end{array}$ & $88 \pm 4$ & $82 \pm 4$ & $89 \pm 5$ \\
\hline
\end{tabular}

Values are given as means \pm SE. Data were compared between control, group 1, and group 2 by one-way ANOVA with factorial analysis. * Data were compared between DD, ID, and II by multiple contingency table analysis. The patients with all three genotypes were indistinguishable in various terms, including the levels of age, sex, urinary protein excretion, serum creatinine, $\mathrm{C}_{\mathrm{cr}}$, and blood pressure.

Among 53 patients, 21 patients were treated with an ACE inhibitor, lisinopril $(10 \mathrm{mg} / \mathrm{d})(11$ patients in group 1 and 10 patients in group 2) and 8 were given a $\mathrm{Ca}$ antagonist ( 2 of group 1 patients and 6 of group 2 patients). For ACE inhibitor administration, patients were randomly selected from patients with normal or moderately impaired renal function $\left(\mathrm{C}_{\mathrm{C}_{\mathrm{r}}}>50 \mathrm{ml} / \mathrm{min}\right)$ before $\mathrm{ACE}$ inhibitor. In these 21 patients with $\mathrm{ACE}$ inhibitor treatment, 24-h $\mathrm{C}_{\mathrm{Cr}}$ and urinary protein excretion rate were monitored every $4 \mathrm{wk}$ and followed for $48 \mathrm{wk}$. These 21 patients included 9 patients with the DD genotype, 6 with the ID genotype, and 6 with the II genotype. The clinical and laboratory features of these three genotypes of patients before treatment of ACE inhibitor are summarized in Table II. All patients were placed on diets containing 7-10 grams/d of $\mathrm{NaCl}$ throughout the study.

Plasma and urine creatinine concentrations were determined by an automated method, using Jaffe reaction. Urine protein concentration was measured by the Lowry method.

Extraction and amplification of genomic DNA. Genomic DNA was purified from peripheral blood with a blood DNA kit (QIAGEN Inc., Chatsworth, CA). Briefly, $10 \mathrm{ml}$ of whole blood cells was lysed in 30 $\mathrm{ml}$ of distilled water and $10 \mathrm{ml}$ of $\mathrm{G} 1$ buffer containing an isotonic buffer designed to stabilize nuclei. Nuclei were collected by centrifugation and lysed in $\mathrm{G} 2$ buffer containing proteinase $\mathrm{K}$. After digestion with proteinase $\mathrm{K}$ at $56^{\circ} \mathrm{C}$ overnight, the solution was passed over a resin column, which was then washed with $1 \mathrm{M} \mathrm{NaCl}$. Genomic DNA was then desalted, and precipitated with isopropanol followed by washing in $70 \%$ ethanol. Genomic DNA was then suspended in $10 \mathrm{mN}$ Tris$\mathrm{HCl}, 1 \mathrm{mM}$ EDTA, pH. 8.0, and concentrations were measured by absorbance at $260 \mathrm{~nm}$.

To determine the ACE genotype of the patients, a genomic DNA fragment on intron 16 of the ACE gene was amplified by PCR according to Rigat's method (35). PCR amplification products were obtained using $50-\mu \mathrm{l}$ reactions $(1 \mu \mathrm{g}$ genomic DNA, 500 pmol primers, $0.5 \mathrm{mM}$ each deoxy-ATP, GTP, CTP, TTP, $3 \mathrm{mM} \mathrm{MgCl} 2$, 1 U Taq DNA polymerase [Takara, Ootsu, Shiga, Japan], $50 \mathrm{mM} \mathrm{KCl}, 0.001 \%$ gelatin, and 10 $\mathrm{mM}$ Tris- $\mathrm{HCl}, \mathrm{pH} 8.3$ ) with $10 \mathrm{~min}$ of denaturation at $94^{\circ} \mathrm{C}$, followed by 30 cycles of $1 \mathrm{~min}$ at $94^{\circ} \mathrm{C}, 1 \mathrm{~min}$ at $58^{\circ} \mathrm{C}$ (annealing), and $2 \mathrm{~min}$ at $72^{\circ} \mathrm{C}$ (extension) in a thermal cycler (PC-700; ASTEC, Fukuoka, Japan). Reaction was terminated at $72^{\circ} \mathrm{C}$ for $2 \mathrm{~min}$. The forward and reverse primers used were 5 '-CTGGAGACCACTCCCATCCTTTCT and 5 '-GATGTGGCCATCACATTCGTCAGAT, respectively. The am- 
plified ACE gene fragments were separated by agarose gel electrophoresis. Fragments without insertion (D allele) and with insertion (I allele) of $\sim 190$ and $\sim 490 \mathrm{bp}$, respectively, were detected on a $1 \%$ agarose gel containing ethidium bromide.

Recently, a study (36) reported that PCR amplification using a primer pair that recognizes insertion-specific sequence identifies $4-5 \%$ of ID genotypes that have been misclassified as DD when only a flanking primer pair was used. To increase the specificity of DD genotyping, therefore, we used a primer pair that recognized the insertion-specific sequence based on a published DNA sequence. Thus, PCR amplifications were performed with an insertion-specific primer pair (5'TGGGACCACAGCGCC CGCCACTAC 3 ' and 5'TCGCCAGCCCTCCCATGCCC-ATAA $\left.3^{\prime}\right)$, with $25-\mu$ l reactions $(0.5 \mu \mathrm{g}$ genomic DNA, 500 pmol of primers, $0.5 \mathrm{mM}$ each deoxy-ATP, GTP, CTP, TTP, 1.5 $\mathrm{mM} \mathrm{MgCl}_{2} ; 0.5 \mathrm{U}$ Taq DNA polymerase [Takara], $50 \mathrm{mM} \mathrm{KCl}, 0.001 \%$ gelatin, and $10 \mathrm{mM}$ Tris- $\mathrm{HCl}, \mathrm{pH} 8.3$ ) with $1 \mathrm{~min}$ of denaturation at $94^{\circ} \mathrm{C}$, followed by 30 cycles of $30 \mathrm{~s}$ at $94^{\circ} \mathrm{C}, 45 \mathrm{~s}$ at $67^{\circ} \mathrm{C}$ (annealing), and $2 \mathrm{~min}$ at $72^{\circ} \mathrm{C}$ (extension). Only the I allele produces a 335-bp amplicon. The 335 -bp fragment was identified on a $1.5 \%$ agarose gel containing ethidium bromide. The reaction yields no products in the samples of DD genotype.

Statistical analyses. Linear regression analysis was used to determine the slope of the $\mathrm{C}_{\mathrm{Cr}}$ plotted against time. To calculate the slope of $\mathrm{C}_{\mathrm{Cr}}$ over time, we used data which had been collected every 4 mo for $>5 \mathrm{yr}$. Thus, each slope is based on at least 15 measurements. $P$ $<0.05$ was regarded as being a statistically significant decline in renal function.

The genotypes and allele frequencies for the deletion/insertion polymorphism were tested by the multiple contingency table analysis for their association with decreased renal function. Odds ratios were calculated as a measure of the association of the ACE genotype with the loss of renal function. For each odds ratio, we calculated $95 \%$ confidence interval and two-tailed $P$ values. The patients with decreased renal function (group 2) were compared with the patients without decreased renal function (group 1) and nonproteinuric controls. These data were unadjusted for age.

Statistical analysis was performed for urine protein excretion by using one-way ANOVA. The data for urine protein excretion were analyzed using the repeated-measures ANOVA to evaluate the statistical significance of the influence of the ACE gene polymorphism on the antiproteinuric effect of ACE inhibitor administration. To evaluate the statistical significance for the difference in the antiproteinuric effect of ACE inhibitor administration between DD versus ID and II, or ID versus II genotype, the one factor ANOVA was used. The data for $\mathrm{C}_{\mathrm{Cr}}$ were analyzed using the repeated-measures ANOVA to evaluate the statistical significance of the influence of the ACE gene polymorphism on the renoprotective effect of ACE inhibitor administration. $P<0.05$ was regarded as being statistically significant.

\section{Results}

The frequency of $D D$ genotypes. In the control group, the frequencies of the D and I alleles were 33 and $67 \%$, and the frequencies of the DD, ID, and II genotypes observed were 7 , 52 , and $41 \%$, respectively. These data are similar to the published data for the Japanese general population (36-38). In IgA patients with stable renal function (group 1), the frequencies of the DD, ID, and II genotypes were 16.0, 36.0, and 48.0\%, respectively (Fig. $1 \mathrm{~A}$ ), with gene frequencies of $\mathrm{D}$ and I allele of 34 and $65 \%$. The expected values which are predicted by the assumption of Hardy-Weinberg equilibrium in control group (DD:ID:II $=11: 44: 45 \%, \chi^{2}=1.88, \mathrm{NS}$ ) and in group 1 (DD:ID:II $=12: 44: 44 \%, \chi^{2}=1.91$, NS) were shown to be similar to those observed in these patients. In patients with declining function (group 2), however, the frequencies of geno- type (DD:ID:II $=43: 29: 29 \%$ ) were significantly different from those seen in the control group $\left(\chi^{2}=14.35, P<0.001\right)$. The difference in distribution pattern between group 1 and 2 , however, did not reach statistical significance for this whole patient population comparison (Fig. $1 A)\left(\chi^{2}=4.70, P\right.$ $=0.09$ ). The $\mathrm{D}$ allele was observed more often among the patients with declining renal function ( $57 \%$ for the $\mathrm{D}$ allele and $43 \%$ for the I allele) than in control (33\% for the D allele and $67 \%$ for the I allele) and in patients with stable renal function ( $34 \%$ for the $\mathrm{D}$ allele and $66 \%$ for the I allele), both differences being significant $\left(\chi^{2}=12.18, P<0.001\right.$, and $\chi^{2}=11.44, P$ $<0.001)$. The observed frequency of genotype in group 2 was significantly different from the Hardy-Weinberg population (DD:ID:II $=33: 49: 18 \%, \chi^{2}=8.98, P<0.05$ ).

Of the 53 patients who satisfied all of the criteria, 45 had normotension at the time of renal biopsy. Within these 45 patients, the genotype distribution in group 2 (DD:ID:II $=50: 29: 21 \%)$ versus that in group 1 (DD:ID:II $=14: 38: 48 \%$ ) was significantly different $\left(\chi^{2}=6.96, P<0.05\right)$ (Fig. $1 B$ ). Of the above 45 patients, 37 had normal renal function. Within these 37 patients, the genotype was also significantly different between group 2 (DD:ID:II $=59: 23: 18 \%$ ) versus group 1 (DD:ID:II $=15: 35: 50 \%, \chi^{2}=8.17, P<0.05$ ) (Fig. $1 C$ ).

To estimate the relative risk for the progressive loss of renal function that the DD genotype carries, the ratio of the DD genotype versus the pooled frequency of the ID and II genotypes in group 2 was compared with that in group 1 (Fig. 2). The DD genotype was significantly more frequent in patients with declining renal function (DD:ID+ II $=43: 57 \%$ ) than that in patients with stable renal function (DD:ID $+\mathrm{II}=16: 84 \%$; odds ratio, 3.94; 95\% confidence interval, 1.07 14.52; $P<0.05$ ). Within patients with normotension at the time of renal biopsy, the DD genotype was significantly more frequent in group 2 (DD:ID+II $=50: 50 \%$ ) than that in group 1 (DD:ID+II $=14: 86 \%$; odds ratio, $6.00 ; 95 \%$ confidence interval, 1.39 25.86; $P<0.05$ ). Within 37 patients with normotension and normal renal function at the time of initial renal biopsy, the DD genotype was found to be significantly more frequent in group 2 (DD:ID+ II $=59: 41 \%$ ) than in group 1 patients with normal renal function (DD:ID+ II $=15: 85 \%$; odds ratio, 8.10; 95\% confidence interval, $1.70 \sim 38.60 ; P<0.01$, Fig. 2).

Among 14 patients who required chronic dialysis (a subset of group 2), 10 patients had normal blood pressure at the time of biopsy. D homozygosity was observed more frequently in these 10 patients (DD:ID+II $=50: 50 \%$ ) than in group 1 patients with normal blood pressure at the time of biopsy (DD:ID+ II $=14: 86 \%$; odds ratio, 6.00 ; $95 \%$ confidence interval, $1.05 \sim 34.21 ; P<0.05)$. Among those 10 patients, 7 patients had normal renal function at the time of biopsy. D homozygosity was observed more often in this subset of group 2 patients (DD:ID+ II $=71: 29 \%$ ) than in group 1 patients with normotension and normal renal function at the time of biopsy (DD:ID+ II = 15:85\%; odds ratio, $14.17 ; 95 \%$ confidence interval, 1.83 109.86; $P<0.005$ ).

The effects of ACE inhibitor on the patients with different genotypes. Data on proteinuria from patients with the DD, ID, and II genotype who were treated with an ACE inhibitor, lisinopril, are shown in Fig. 3. These three groups were indistinguishable for age, sex, baseline blood pressure, urinary protein excretion rate, serum creatinine levels, and $\mathrm{C}_{\mathrm{Cr}}$ (Table II).

In $\mathrm{D}$ homozygotes, urinary protein excretion significantly 


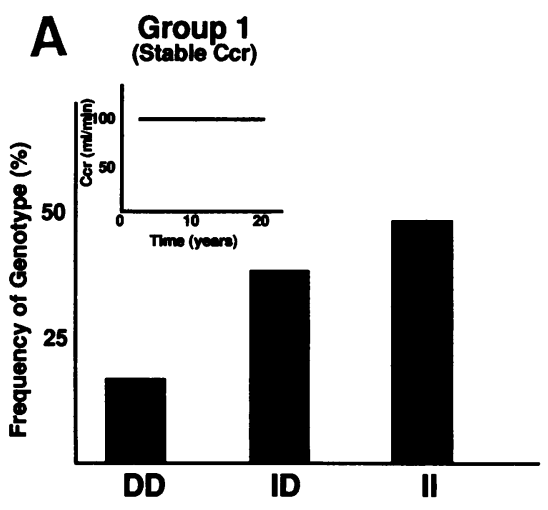

B

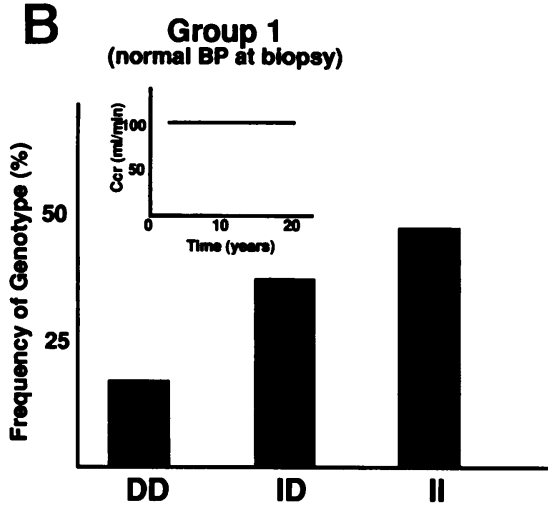

C

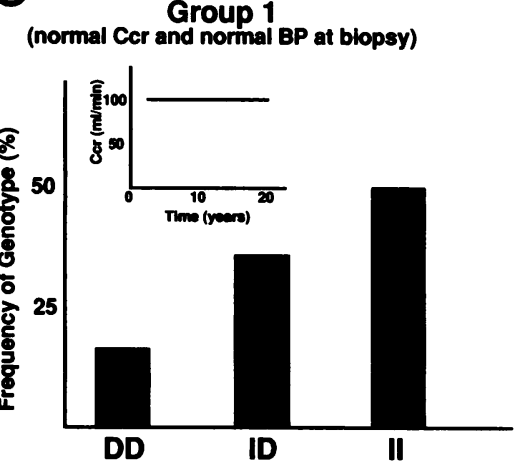

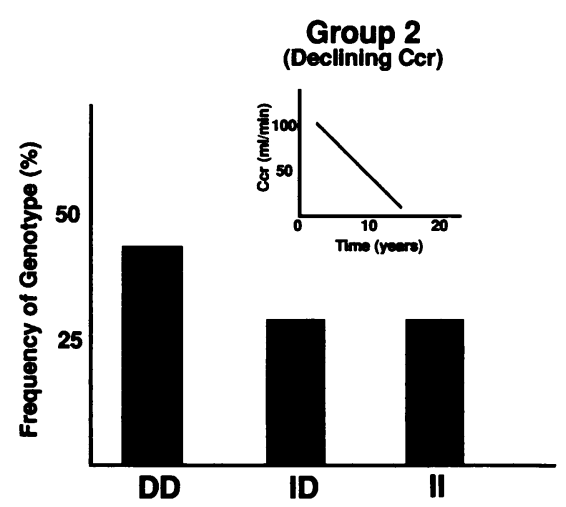
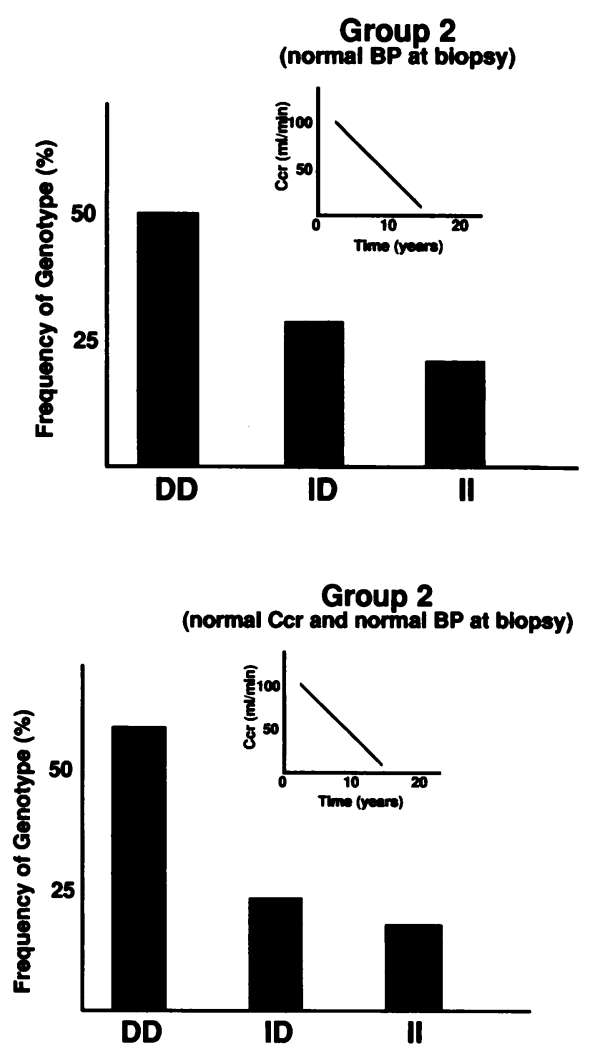

Figure 1. (A) The imbalance of D polymorphism of the ACE gene between patients with stable renal function versus those with declining renal function. In patients with declining renal function (Group 2), the frequency of genotype was significantly different from that seen in the control group. The difference in distribution pattern between patients with stable renal function (Group 1) and group 2, however, did not reach statistical significance for whole patient population comparison $\left(\chi^{2}=4.70, P=0.09\right)$. Probability was determined by contingency table analysis. $(B)$ The imbalance of deletion polymorphism in the ACE gene between group 1 versus group 2 patients with normal blood pressure at the time of renal biopsy. Among patients with normal blood pressure at the time of renal biopsy, the frequency of genotype was significantly different between group 1 versus group 2 . These differences were statistically significant $\left(\chi^{2}=6.96, P\right.$ $<0.05$ ). Probability was determined by contingency table analysis. $(C)$ The imbalance of deletion polymorphism in the ACE gene between group 1 versus group 2 patients with normal renal function and normal renal function at the time of renal biopsy. Among patients with normal renal function at the time of renal biopsy, the frequency of genotype was significantly different between group 1 versus group 2 . These differences were statistically significant $\left(\chi^{2}=8.17, P<0.05\right)$. Probability was determined by contingency table analysis. decreased after ACE inhibitor administration $(1.402 \pm 0.399$ at 0 wk vs. $0.0618 \pm 0.108 \mathrm{grams} / \mathrm{d}$, at $12 \mathrm{wk}$, NS, and $0.586 \pm 0.096$ grams $/ \mathrm{d}$, at $24 \mathrm{wk}, \mathrm{NS}, 0.469 \pm 0.098 \mathrm{grams} / \mathrm{d}$, at $36 \mathrm{wk}, P$ $<0.05$, and $0.379 \pm 0.078 \mathrm{grams} / \mathrm{d}$, at $48 \mathrm{wk}, P<0.05)$, but not in those with ID $(1.400 \pm 0.173 \mathrm{grams} / \mathrm{d}$ at $0 \mathrm{wk}$, vs. $1.102 \pm 0.257$ grams/d, at $12 \mathrm{wk}$, NS, and $1.017 \pm 0.198$ grams/ $\mathrm{d}$, at $24 \mathrm{wk}, \mathrm{NS}, 1.248 \pm 0.214 \mathrm{grams} / \mathrm{d}$, at $36 \mathrm{wk}$, NS, and $1.302 \pm 0.263 \mathrm{grams} / \mathrm{d}$, at $48 \mathrm{wk}$, NS) nor II genotype $(1.428 \pm 0.350 \mathrm{grams} / \mathrm{d}$ at $0 \mathrm{wk}, 1.327 \pm 0.031 \mathrm{grams} / \mathrm{d}$, at 12 wk, NS, $1.467 \pm 0.378 \mathrm{grams} / \mathrm{d}$, at $24 \mathrm{wk}$, NS, $1.368 \pm 0.257$ $\mathrm{grams} / \mathrm{d}$, at $36 \mathrm{wk}, \mathrm{NS}$, and $1.680 \pm 0.289 \mathrm{grams} / \mathrm{d}$, at $48 \mathrm{wk}$, NS). ANOVA revealed that the proteinuria-reducing effect of ACE inhibition was significantly different between patients with the DD genotype versus those with ID $(P<0.05)$ and II $(P$ $<0.05$ ) genotypes at 36 and $48 \mathrm{wk}$. Although the pattern of the response of the ID genotype is numerically midway between those of II and DD (Fig. 3), no statistical significance is reached for the difference between II and ID genotypes.

After ACE inhibition, the mean value of $\mathrm{C}_{\mathrm{Cr}}$ in the DD genotype did not significantly decrease within $48 \mathrm{wk}$ ( $71.7 \pm 9.0$ $\mathrm{ml} / \mathrm{min}$ at 0 wk vs. $65.4 \pm 8.2 \mathrm{ml} / \mathrm{min}$ at $12 \mathrm{wk}, \mathrm{NS} ; 66.4 \pm 8.1$ $\mathrm{ml} / \mathrm{min}$ at $24 \mathrm{wk}, \mathrm{NS} ; 60.5 \pm 5.2 \mathrm{ml} / \mathrm{min}$ at $36 \mathrm{wk}, \mathrm{NS} ; 60.6 \pm 8.3$ $\mathrm{ml} / \mathrm{min}$ at $48 \mathrm{wk}, \mathrm{NS}$ ). As in patients with the DD genotype, $\mathrm{C}_{\mathrm{Cr}}$ did not significantly decrease after ACE inhibition in the group of patients with the ID $(81.7 \pm 3.4 \mathrm{ml} / \mathrm{min}$ at $0 \mathrm{wk}$ vs. $80.5 \pm 7.4 \mathrm{ml} / \mathrm{min}$ at $12 \mathrm{wk}, \mathrm{NS} ; 103.7 \pm 10.9 \mathrm{ml} / \mathrm{min}$ at $24 \mathrm{wk}$, $\mathrm{NS} ; 90.5 \pm 7.1 \mathrm{ml} / \mathrm{min}$ at $36 \mathrm{wk}, \mathrm{NS} ; 92.17 \pm 10.2 \mathrm{ml} / \mathrm{min}$ at 48 wk, NS) and II genotypes $(80.0 \pm 7.8 \mathrm{ml} / \mathrm{min}$ in $0 \mathrm{wk}$ vs. $61.5 \pm 9.9 \mathrm{ml} / \mathrm{min}$ in $12 \mathrm{wk}$, NS; $70.7 \pm 8.7 \mathrm{ml} / \mathrm{min}$ in $24 \mathrm{wk}$, $\mathrm{NS} ; 72.3 \pm 7.5 \mathrm{ml} / \mathrm{min}$ in $36 \mathrm{wk}, \mathrm{NS} ; 77.3 \pm 10.8 \mathrm{ml} / \mathrm{min}$ in 48 wk, NS). Although patients with declining renal function (group 2) more often had the DD genotype and patients with 


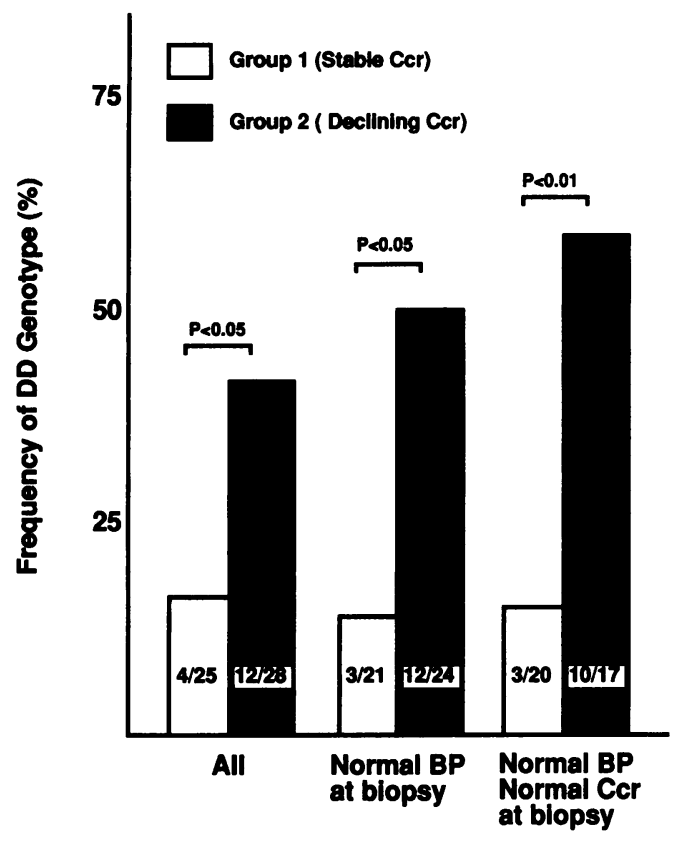

Figure 2. Frequency of the DD genotype in patients with normal blood pressure and/or normal renal function at the time of renal biopsy. Among patients with normal blood pressure at the time of renal biopsy, the DD genotype was observed significantly more frequently in group 2 than group $1\left(\chi^{2}=6.43, P<0.05\right)$. Among patients with normal blood pressure and normal renal function at the time of renal biopsy, the DD genotype was observed significantly more frequently in group 2 than in group $1\left(\chi^{2}=7.74, P<0.01\right)$. All, all patients with $\operatorname{IgA}$ nephropathy $(n=53)$. Normal BP at biopsy, patients with normal blood pressure at the time of renal biopsy $(n=45)$. Normal BP Normal Ccr at biopsy, patients with normal blood pressure and normal creatinine clearance rate at the time of renal biopsy $(n=37)$. The number of patients with the DD genotype and the total number of patients in each category are given. For instance, of all of the 53 patients studied, 25 belonged to group 1 . Of the 25,4 had the DD genotype, so that the DD genotype was $4 / 25 \times 100=16 \%$. Probabilities were determined by contingency table analysis. The ratio between the DD genotype versus the pooled frequency of the ID and II genotypes in group 2 was compared with that in group 1 .

stable renal function (group 1) more often had the II genotype, this $\mathrm{C}_{\mathrm{Cr}}$ response to $\mathrm{ACE}$ inhibitor was not significantly different between the patients with the DD genotype versus those with the ID or the II genotype within 48 wk of ACE inhibitor administration.

Since group 2 patients were more often patients with DD genotype and group 1 patients were more often the II genotype (Table III), it is unclear whether the effects of ACE inhibitor on proteinuria are associated with the reduced $\mathrm{C}_{\mathrm{Cr}}$ in group 2 . To clarify this issue, we performed the following two analyses: (a) correlation between the genotype and the response in proteinuria to ACE inhibitor within group 2: a significantly greater response was found in DD genotype (1.617 $\pm 0.480 \mathrm{grams} / \mathrm{d}$ at 0 wk vs. $0.713 \pm 0.109$ grams $/ \mathrm{d}$, at $12 \mathrm{wk}$, NS, and $0.640 \pm 0.110$ grams $/ \mathrm{d}$, at $24 \mathrm{wk}, \mathrm{NS}, 0.531 \pm 0.115 \mathrm{grams} / \mathrm{d}$, at $36 \mathrm{wk}, P$ $<0.05$, and $0.396 \pm 0.096 \mathrm{grams} / \mathrm{d}$ at $48 \mathrm{wk}, P<0.05)$ than in the other genotypes $(1.007 \pm 0.436 \mathrm{grams} / \mathrm{d}$ at $0 \mathrm{wk}$ vs. $1.017 \pm 0.0 .401 \mathrm{grams} / \mathrm{d}$, at $12 \mathrm{wk}, \mathrm{NS}$, and $0.72 \pm 0.231$ grams/ $\mathrm{d}$, at $24 \mathrm{wk}, \mathrm{NS}, 0.937 \pm 0.451 \mathrm{grams} / \mathrm{d}$, at $36 \mathrm{wk}$, NS, and

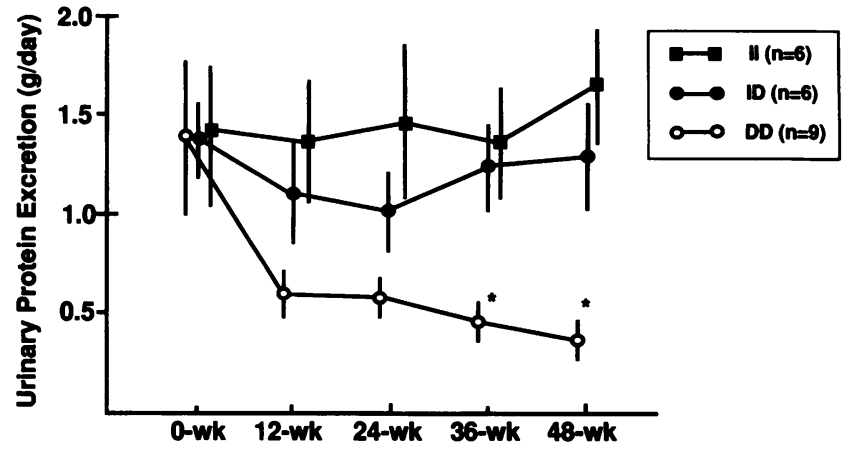

Figure 3. Difference in the antiproteinuric effect of ACE inhibitor between patients with the DD genotype versus those with the ID genotype or the II genotype. ANOVA revealed that the antiproteinuric effect of ACE inhibition was significantly different between patients with versus without the DD genotype. Between patients with the DD genotype versus the ID genotype or II genotype, the antiproteinuric effect of ACE inhibition was significantly different in $36(P<0.05)$ and $48 \mathrm{wk}(P$ $<0.05$ ). Although the pattern of the response of the ID genotype is numerically between those of II and DD, no statistical significance is reached for the difference between II and ID. $* P<0.05$ versus 0 -wk data obtained immediately before the start of ACE inhibitor administration. 12-, 24-, 36-, and 48 -wk data were obtained after 12, 24, 36, and 48 wk of ACE inhibitor administration, respectively. Values are given as means $\pm 1 \mathrm{SE}$.

$0.923 \pm 0.459$ grams $/ \mathrm{d}$, at $48 \mathrm{wk}, \mathrm{NS}$ ) although the number of patients, II+ID $=3$, was too small to be conclusive; and ( $b$ ) correlation between ACE inhibitor-induced changes in proteinuria and the level of $\mathrm{C}_{\mathrm{Cr}}$ at the onset of ACE inhibitor administration: no significant correlation was found $(r=0.12$, NS, for $12 \mathrm{wk}, r=0.26$, NS, for $24 \mathrm{wk}, r=0.10$, NS, for $36 \mathrm{wk}, r$ $=0.14$, NS, for $48 \mathrm{wk}$ ). Thus, the antiproteinuric effect of ACE inhibitor is closely dependent on the genotype but not the absolute level of $\mathrm{C}_{\mathrm{Cr}}$.

\section{Discussion}

In this study, it was found that a deletion polymorphism in the ACE gene has a significant association with the incidence of progressive deterioration of renal function in IgA nephropathy. The patients with progressive decline in renal function were also characterized by a higher incidence of hypertension and an initially mildly reduced renal function, a finding consistent with the prevailing notion that these two clinical and laboratory findings are risk factors predicting the progression to renal failure in this disease (39-42). Our data suggest the possibility that these and other initial clinical and laboratory signs are also associated with the presence of the ACE gene deletion polymorphism. For example, the frequency of the DD genotype was higher in patients with declining renal function (43\%) than in those with stable renal function (16\%). Also, it was of higher frequency in the IgA nephropathy patient population as a whole $(30 \%)$ than in the Japanese general population, which is estimated to be $\sim 10 \%(39)$. These associations suggest that the presence of the DD genotype may shift IgA nephropathy from mild to severe, and nephropathy from subclinical to overt. Thus, the presence or absence of the DD ACE genotype may modify the severity and/or course of subclinical IgA nephropathy that 


\begin{tabular}{|c|c|c|c|c|c|c|}
\hline & \multirow[b]{2}{*}{ Control } & \multirow[b]{2}{*}{ Group 1} & \multirow[b]{2}{*}{ Group 2} & \multicolumn{3}{|c|}{ Odds ratio $(95 \% \mathrm{CI})$} \\
\hline & & & & Control vs. group 1 & Group 1 vs. group 2 & Control vs. group 2 \\
\hline \multicolumn{7}{|c|}{ All subjects } \\
\hline DD & 5 & 4 & 12 & $2.66(0.55-13.02)$ & $3.94(1.07-14.52)^{*}$ & $4.62(2.61-42.16)^{\ddagger}$ \\
\hline ID+II & 41 & 21 & 16 & & & \\
\hline \multicolumn{7}{|c|}{$\begin{array}{l}\text { Patients with normal BP at } \\
\text { biopsy }\end{array}$} \\
\hline DD & & 3 & 12 & & $6.00(1.39-25.86)^{*}$ & \\
\hline ID+II & & 18 & 12 & & & \\
\hline \multicolumn{7}{|c|}{$\begin{array}{c}\text { Patients with normal BP and } \\
\text { normal } C_{c r} \text { at biopsy }\end{array}$} \\
\hline DD & & 3 & 10 & & $8.10(1.70-38.60)^{8}$ & \\
\hline ID+II & & 17 & 7 & & & \\
\hline
\end{tabular}

Odds ratios were unadjusted for age and sex. $C I$, confidence interval. ${ }^{*} P<0.05,{ }^{8} P<0.01,{ }^{\ddagger} P<0.005$.

has been detected in screening of one million school children in Japan (43). Alternatively, the ACE gene may be physically linked to another(other) gene (genes) on the D-carrying chromosome that directly causes the progression of $\operatorname{IgA}$ nephropathy. In this case, the D polymorphism of the ACE gene may serve only as a prognostic marker. Regardless of the true functional locus on the chromosome, the ACE gene polymorphism under study appears to be clinically important across populations with diverse genetic and environmental background, as our most recent preliminary study (44) has shown a significant correlation between $\mathrm{D}$ allele and reduction in filtration function among Caucasian population with IgA nephropathy as well.

In the present study, detailed analysis of our IgA nephropathy patients further revealed that, in a subpopulation of patients with normal renal function and in another subpopulation of those without hypertension at the time of biopsy, a significant association also exists between the presence of polymorphism and progressive loss of renal function. These results are analogous to those occurring in cardiomyopathy as previously discussed $(18,19,26)$. Indeed, the odds ratio to develop left ventricular hypertrophy was found by Schunkert et al. (26) to be substantially higher among normotensive than hypertensive individuals. From the study of cardiomegaly, one may infer that the deleterious effects of the ACE D polymorphism may be mediated through pathogenic effects at the local tissue level rather than systemic hypertension. However, without extensive blood pressure monitoring data, the possibility remains that a subtle ACE gene-dependent abnormality in blood pressure may mediate the progression of IgA nephropathy.

Inspection of data from individual patients with progressive IgA nephropathy suggests that other factors contribute to the progression of the disease. For example, the clinical course of these patients was not uniform, i.e., some patients required chronic dialysis within 5-10 yr after onset, and the renal function of others slowly progressed to renal failure over a period of $20 \mathrm{yr}$ after onset of the first symptoms. Variable histologic findings were also observed in the patients with progressive IgA nephropathy $(42,45,46)$. Thus, multiple factors, such as immunologic abnormalities, i.e., high levels of serum IgA, hyperactivity of helper $\mathrm{T}$ cells (47), and high levels of serum cytokines derived from $\mathrm{T}$ cells, etc. (29), may be involved in determining the progression of IgA nephropathy. Interestingly, a DNA polymorphism of the T cell receptor $\beta$ chain gene was recently reported to be associated with the progression of $\operatorname{IgA}$ nephropathy (48). In addition, as in many other chronic renal diseases, nonimmunologic factors are also likely to influence the progression of IgA nephropathy. If proteinuria and hypertension represent the early signs of progressive $\operatorname{IgA}$ nephropathy, it is possible that these clinical indexes for progression are also, in part, mediated by a genetic predisposition, such as the ACE D polymorphism.

In many chronic renal diseases, administration of an ACE inhibitor leads to a significant attenuation of proteinuria (16, $49,50)$. Interestingly, it has been recently reported (51) that, in patients with insulin-dependent diabetes with normal renal function, the absence of the D polymorphism decreases the probability of development of microalbuminuria or proteinuria, but a strong correlation was not demonstrated in another study (52). Thus, in both IgA nephropathy and diabetic nephropathy, the presence of proteinuria may act as a risk factor for chronic renal failure, conceivably because proteinuria and progression share the same genetic risk factor, namely, the D polymorphism of the ACE gene. However, it is speculative since it has not been established in diabetes that the $\mathrm{D}$ polymorphism is associated with progression to renal failure, nor that, in $\operatorname{IgA}$ nephropathy, proteinuria per se predicts the course of the disease. Furthermore, all of our patients were on a variety of medications which might themselves modify the levels of urinary protein and hypertension.

Because ACE inhibitors, which dampen the increased ACE activity, are readily available, the genetic predisposition of some IgA patients can, at least theoretically, be overcome therapeutically. In this regard, in IgA nephropathy, administration of an ACE inhibitor has been demonstrated to reduce urinary protein excretion and to attenuate the progression of glomerular injury to a variable degree (17). The apparent variability in the effectiveness of ACE inhibition on proteinuria and progressive decline in renal function in IgA nephropathy may be attributed to the strong dependency of the efficacy of ACE inhibition on the genetic background of patients. In our study, proteinuria was 
indeed significantly decreased after ACE inhibition in patients with the DD genotype while it was without statistically significant effect in patients with II and ID genotypes. In addition, $\mathrm{C}_{\mathrm{Cr}}$ was not significantly altered after ACE inhibition in patients regardless of the ACE genotype, due presumably in part to the short observation period.

In summary, we observed a significant association between the D polymorphism of the ACE gene and the progressive loss of renal function in patients with IgA nephropathy. Moreover, presence of this polymorphism was associated with increased efficacy of ACE inhibition on proteinuria. Further studies are warranted to verify these findings and to clarify if, in IgA nephropathy patients with the $\mathrm{D}$ polymorphism, their predisposition to renal failure can be significantly modified or altered by ACE inhibition or another pharmacologic intervention.

\section{Acknowledgments}

We thank Dr. John A. Phillips III of Vanderbilt University for his advice during the preparation of this manuscript.

This work was supported in part by a Scientific Research Grant from the Ministry of Education, Science and Culture, Japan (No. 06770880) and National Institute of Diabetes and Digestive and Kidney Disease grants DK-37868 and DK-44757.

\section{References}

1. Julian, B., F. Waldo, A. Refai, and J. Mesteeky. 1988. IgA nephropathy, the most common glomerulonephritis worldwide. Am. J. Med. 84:129-132.

2. Berger, J. 1969. IgA glomerular deposits in renal disease. Transplant. Proc. 1:939-944.

3. Sakai, O., T. Kitajima, K. Kawamura, and Y. Ueda. 1979. Clinicopathological studies on IgA glomerulonephritis. In Glomerulonephritis. Y. Yoshitoshi and Y. Ueda, editors. University of Tokyo Press, Tokyo. 167-179.

4. Kitajima, T., M. Murakami, and O. Sakai. 1983. Clinico-pathological features in Japanese patients with IgA nephropathy. Jpn. J. Med. 22:219-222.

5. D'Amico, G. 1988. Clinical features and natural history in adults with IgA nephropathy. Am. J. Kidney Dis. 12:353-357.

6. Alamartine, E., J. Sabatier, C. Guerin, J. M. Berliet, and F. Berthoux. 1991. Prognostic factors in mesangial IgA glomerulonephritis: an extensive study with univariate and multivariate analysis. Am. J. Kidney Dis. 18:12-19.

7. Klahr, S., G. Schreiner, and I. Ichikawa. 1988. The progression of renal disease. N. Engl. J. Med. 318:1657-1665.

8. Kakinuma, Y., T. Kawamura, T. Bills, T. Yoshioka, I. Ichikawa, and A Fogo. 1992. Blood pressure-independent effect of angiotensin inhibition on the glomerular and non-glomerular vascular lesions of chronic renal failure. Kidney Int. 42:46-55.

9. Anderson, S., H. G. Rennke, and B. M. Brenner. 1986. Therapeutic advantage of converting enzyme inhibitors in arresting progressive renal disease associated with systemic hypertension in the rat. J. Clin. Invest. 77:1993-2000.

10. Lewis, E. J., L. G. Hunsicker, R. P. Bain, and R. D. Rohde. 1993. The effect of angiotensin-converting enzyme inhibition on diabetic nephropathy. $N$. Engl. J. Med. 329:1456-1462.

11. Hommel, E., H. H. Parving, E. Mathiesen, B. Edsberg, M. Damkhaer Nielsen, and J. Giese. 1986. Effect of captopril on kidney function in insulindependent diabetic patients with nephropathy. Br. Med.J. 293:467-470.

12. Björck, S., G. Nyberg, H. Mulec, G. Granerus, H. Herlitz, and M. Aurell. 1986. Beneficial effects of angiotensin converting enzyme inhibition on renal function in patients with diabetic nephropathy. Br. Med. J. 293:471-474.

13. Parving, H. H., E. Hommel, and U. M. Smidt. 1988. Protection of kidney function and decrease in albuminuria by captopril in insulin dependent diabetics with nephropathy. Br. Med. J. 297:1086-1091.

14. ter Wee, P., and M. Epatein. 1993. Angiotensin-converting enzyme inhibitors and progression of nondiabetic chronic renal disease. Arch. Intern. Med. 153:1749-1759.

15. Rekola, S., A. Bergstrand, and H. Bucht. 1991. Deterioration rate in IgA nephropathy: comparison of a converting enzyme-inhibitor and $\beta$-blocking agents. Nephron. 59:57-60.

16. Remuzzi, A., E. Perticucci, P. Ruggenenti, L. Mosconi, M. Limonta, and G. Remuzzi. 1991. Angiotensin converting enzyme inhibition improves glomerular size-selectivity in IgA nephropathy. Kidney Int. 39:1267-1273.
17. Cattran, D. C., C. Greenwood, and S. Ritchie. 1994. Long-term benefit of angiotensin-converting enzyme inhibitor therapy in patients with severe immunoglobulin A nephropathy: a comparison to patients receiving treatment with other antihypertensive agents and to patients receiving no therapy. Am. J. Kidney Dis. 23:247-254

18. Marian, A. J., Q. T. Yu, R. Workman, G. Greve, and R. Roberts. 1993. Angiotensin-converting enzyme polymorphism in hypertrophic cardiomyopathy and sudden cardiac death. Lancet. 342:1085-1086.

19. Raynolds, M. V., M. R. Bristow, E. W. Busy, W. T. Abraham, B. D. Lower, L. S. Zisman, C. S. Taft, and M. B. Perryman. 1993. Angiotensin-converting enzyme DD genotype in patients with ischaemic or idiopathic dilated cardiomyopathy. Lancet. 342:1073-1075.

20. Tiret, L., F. Kee, O. Poirier, V. Nicaud, L. Lecerf, A. Evans, J. P. Cambou, D. Arveiler, G. Luc, P. Amouyel, and F. Cambien. 1993. Deletion polymorphism in angiotensin-converting enzyme gene associated with parental history of myocardial infarction. Lancet. 341:991-992.

21. Cambien, F., O. Poirier, L. Lecerf, A. Evans, J. P. Cambou, D. Arveiler, G. Luc, J. M. Bard, L. Bara, S. Ricard, et al. 1992. Deletion polymorphism in the gene for angiotensin-converting enzyme is a potent risk factor for myocardial infarction. Nature (Lond.). 359:641-644.

22. Linz, W., B. A. Scholkens, and D. Ganten. 1989. Converting enzyme inhibition specifically prevents the development and induces regression of cardiac hypertrophy in rats. Clin. Exp. Hypertens. 11:1325-1350.

23. Cloze, J. P., H. Kuhn, and F. Hefti. 1989. Effects of chronic ACE inhibition on cardiac hypertrophy and coronary vascular reserve in spontaneously hypertensive rats with developed hypertension. J. Hypertens. 7:267-275.

24. Dzau, V. J. 1993. Angiotensin and the Heart. H. Grobecker, G. Heusch, and B. E. Strauer, editors. Springer Verlag, New York. 1-14.

25. Rigat, B., C. Hubert, F. Alhenc-Gelas, F. Cambien, P. Corvol, and F. Soubrier. 1990. An insertion/deletion polymorphism in the angiotensin I converting enzyme gene accounting for half the variance of serum enzyme levels. $J$. Clin. Invest. 86:1343-1346.

26. Schunkert, H., J. W. Hense, S. R. Holmer, M. Stender, S. Perz, U. Keil, B. H. Lorell, and G. A. Reigger. 1994. Association between a deletion polymorphism of the angiotensin-converting-enzyme gene and left ventricular hypertrophy. N. Engl. J. Med. 330:1634-1638.

27. Hubert, C., A. Houot, P. Corvol, and F. Soubrier. 1991. Structure of the angiotensin I-converting enzyme gene. Two alternate promoters correspond to evolutionary steps of a duplicated gene. J. Biol. Chem. 266:15377-15383.

28. Tiret, L., B. Rigat, S. Visvikis, C. Breda, P. Corvol, F. Cambien, and F. Soubrier. 1992. Evidence, from combined segregation and linkage analysis, that a variant of the angiotensin I-converting enzyme (ACE) gene controls plasma levels. Am. J. Hum. Genet. 51:197-205.

29. Costerousse, O., J. Allegrini, M. Lopez, and F. Alhenc-Gelas. 1993. Angiotensin 1-converting enzyme in human circulating mononuclear cells: genetic polymorphism of expression in T-lymphocytes. Biochem. J. 290:33-40.

30. Higashimori, K., Y. Zhao, J. Higaki, A. Kamitani, T. Katsuya, J. Nakura, T. Miki, H. Mikami, and T. Ogihara. 1993. Association analysis of a polymorphism of the angiotensin converting enzyme gene with essential hypertension in the Japanese population. Biochem. Biophys. Res. Commun. 191:399-404.

31. Zee, R. Y., Y. K. Lou, L. R. Griffiths, and B. J. Morris. 1992. Association of a polymorphism of the angiotensin I-converting enzyme gene with essential hypertension. Biochem. Biophys. Res. Commun. 184:9-15.

32. Bohn, M., K. E. Berge, A. Bakken, J. Erikssen, and K. Berg. 1993. Insertion/deletion polymorphism at the locus for angiotensin 1-converting enzyme and parental history of myocardial infarction. Clin. Genet. 44:298-301.

33. Bohn, M., K. E. Berge, A. Bakken, J. Erikssen, and K. Berg. 1993. Insertion/deletion polymorphism at the locus for angiotensin 1-converting enzyme and myocardial infarction. Clin. Genet. 44:292-297.

34. Schmidt, S., I. M. van Hooft, D. E. Grobbee, D. Ganten, and E. Ritz. 1993. Polymorphism of the angiotensin 1-converting enzyme gene is apparently not related to high blood pressure: Dutch hypertension and offspring study. $J$. Hypertens. 11:345-348.

35. Rigat, B., C. Hubert, P. Colvol, and F. Soubrier. 1992. PCR deletion of the insertion/deletion polymorphism of the human angiotensin converting enzyme gene (DCP1) dipeptidedyl carboxypeptidase 1. Nucleic Acids Res. 20:433.

36. Lindpaintner, K., M. A. Pfeffer, R. Kreutz, M. J. Stampfer, F. Grodstein, F. LaMotte, J. Buring, and H. Hennekens. 1995. A prospective evaluation of an angiotensin-converting-enzyme gene polymorphism and the risk of ischemic heart disease. $N$. Engl. J. Med. 332:706-711.

37. Higashiori, K., Y. Zhao, J. Higaki, A. Kimitani, T. Katsuya, J. Nakura, and T. Miki. 1993. Association analysis of a polymorphism of the angiotensin converting enzyme gene with essential hypertension in the Japanese population. Biochem. Biophys. Res. Commun. 191:399-404.

38. Nomura, H., I. Koni, Y. Michishita, T. Morise, and R. Takeda. 1994. Angiotensin-converting enzyme gene polymorphism in haemodialysis patients. Lancet. 343:482-483.

39. Beukhof, J., O. Kardaun, W. Schaafsma, K. Poortena, A. Donker, P. 
Hoedemaeker, and G. Van Der Hem. 1986. Toward individual prognosis of IgA nephropathy. Kidney Int. 29:549-556

40. Rekola, S. A., H. Bergstand, and H. Bucht. 1990. Development of hypertension in IgA nephropathy as a marker of poor prognosis. Am. J. Nephrol. 10:191-197.

41. Nicholls, K., K. Fairly, J. Dowling, and P. Kincade-Smith. 1984. The clinical course of mesangial IgA associated nephropathy in adults. Q. J. Med. 53:227-250.

42. D’Amico, G., E. Imbasciati, G. Barbiano Di Belgiojoso, S. Bertoli, G. Fogazzi, F. Ferrario, G. Fellin, A. Ragni, G. Colosanti, L. Minetti, and C. Ponticelli. 1985. Idiopathic IgA mesangial nephropathy: clinical and histological studies of 374 patients. Medicine (Baltimore). 64:49-60.

43. Iitaka, K. 1994. Pediatric nephrology from around the world. Japan: screening problems. In Pediatric Nephrology. 3rd ed. M. A. Holiday, T. A. Barrett, and E. D. Avener, editors. Williams \& Wilkins, Baltimore. 1434-1435.

44. Hunley, T. E., B. A. Julian, N. J. Phillips, N. J. Brown, H. Yoshida, I. Ichikawa, and V. Kon. 1995. Does angiotensin converting enzyme (ACE) gene deletion polymorphism predict progressive renal damage in IgA nephropathy? Pediatr. Res. In press.

45. Echoic, N., H. Iwo, and H. Newcomer. 1992. Prognostic indicators in childhood IgA nephropathy. Nephron. 60:60-67.
46. Navy, J., C. Train, G. Dark, M. Schmelzer, and T. Burger. 1984. The role of tubulointerstitial changes in the prognosis of IgA nephropathy. Klin. Wochenschr. 62:1094-1096.

47. de Caestecker, M., M. Bottomly, B. Telfer, I. Hutchinson, B. Vose, and F. Ballardie. 1993. Detection of abnormal peripheral blood mononuclear cell cytokines networks in human IgA nephropathy. Kidney Int. 44:1298-1308.

48. Nagasawa, R., O. Mastumura, N. Marayama, T. Mitarai, and K. Isoda. 1995. Influence of the T-cell receptor b-chain gene on the progression of IgA nephropathy in Japanese patients. Nephron. In press.

49. Docci, D., G. Moscatelli, C. Capponcini, L. Baldrati, and C. Feletti. 1992. Nephrotic-range proteinuria in a patient with high renin hypertension: effect of treatment with an ACE-inhibitor. Am. J. Nephrol. 12:387-389.

50. Allon, M., C. B. Pasque, and M. Rodriguez. 1990. Acute effects of captopril and ibuprofen on proteinuria in patients with nephrosis. J. Lab. Clin. Med. 116:462-468.

51. Marre, B., P. Bernadet, Y. Gallois, F. Savagner, T. T. Guyene, M. Hallab, F. Cambein, P. Passa, and F. Alhenc-Gelas. 1994. Relationships between angiotensin I-converting enzyme gene polymorphism, plasma levels, and diabetic retinal and renal complications. Diabetes. 43:384-388.

52. Doria, A., J. H. Warram, and A. S. Krolewski. 1994. Genetic predisposition to diabetic nephropathy. Evidence for a role of the angiotensin 1-converting enzyme gene. Diabetes. 43:690-695 